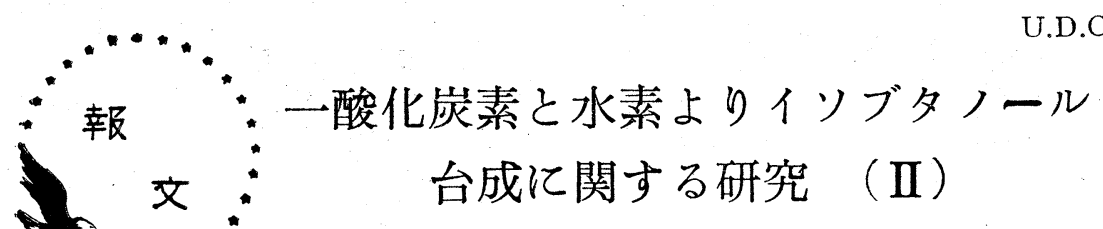

一一昭和 35 年 6 月 27 日受理一

住友化学工業株式会社 後藤敏英

要旨：一第 1 報に颃いて Zn-フルカリ系に対し酸化クロムが最適の促進剤であることがわかつた ので, 本報に拈いては Zn-Cr-フルカリ系に対し各種金属酸化物の影響を調べた。その結果 Mo, Th, W が良好であり，そのうち Mo が最も優秀であつた。Zn-アルカリ系の場合 Mo の添加は水 の生成のみを促進したが，Cr との共存により優季な性能を示すことを発見した。特に Mo の特徴 としては生成水が理論量よりも少く $(2 n-1) \mathrm{CO}+(n+1) \mathrm{H}_{2}=\mathrm{C}_{n} \mathrm{H}_{2 n+1} \mathrm{OH}+(n-1) \mathrm{CO}_{2}$ の反応を促進 していると考えられる。

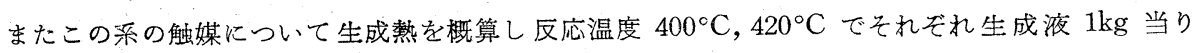
$1,354 \mathrm{kcal}, 1,674 \mathrm{kcal}$ を得た。

\section{I 緒言}

第 1 報に報告したように酸化亜鉛に炭酸カリ 20 重 量\%添加したものに $\mathrm{Mg}, \mathrm{Al}, \mathrm{Ur}, \mathrm{Th}, \mathrm{Ce}, \mathrm{Cr}, \mathrm{Fe}, \mathrm{Mn}$, $\mathrm{V}, \mathrm{Mo}$ な゙の各種金属酸化物を添加した場合の影響を 見たが, 酸化ク口ムの場合が最良で生成液;量 $3.8 \mathrm{gr} /$ cat.cc/日，イソブタノール収率 $17.9 \%$ すなわちイソ ブタノール収量, $14.6 \mathrm{gr}$./原料ガス中 $\mathrm{CO}, \mathrm{m}^{3}$ を得た。

そこで筆者は良好と考えられる亜鉛，クロムの酸化 物一炭酸カリ系に各種金属酸化物を添加し, その効果 を実験した。また最良と考えられる結果について生成 熱を計算した。

\section{II 実験装置および実験方法}

実験装置および実験方法は大体第 1 報と同様である が, 異なる所は次のとおりである。

原料ガスはメタノール合成用原料ガスを減圧してガ スタンクに導き, 別に用意した CO を補給し所要の $\mathrm{CO}: \mathrm{H}_{2}$ にして原料ガスとした。

補給する一酸化炭素はガス工場銅アンモニア吸収塔 からでたガスから炭酸ガスをアルカリ洗浄塔で除去し て準備したものである。触媒還元用としてはメタノ一 ル原料ガスを使用した。

かくして調整した原料ガスをルックスマスを充填し た無機脱硫槽に導き硫化水素を除去し，つぎに有機イ オウ脱却塔をとおした。この触媒はアルミナ工場の廃 呆物の赤泥に炭酸ソーダを40\%添加し団粒にして空気 中で $500^{\circ} \mathrm{C}$ に焼成したものである。脱硫条件は空間 速度 300 , 温度 $200 \sim 250^{\circ} \mathrm{C}$ を使用した。脱硫率が低
下すると 300〜 $350^{\circ} \mathrm{C}$ で空気をとおし賦活した。かく して全イオウ含有量を $0.2 \mathrm{gr} / 100 \mathrm{~m}^{3}$ 以下にすることが できた。このガスを第 1 報と同様な方法で使用した。

また原料ガスを圧縮後高圧下で脱硫を行ら方法も行 つた。触媒は前記と同様のものを使用し反応条件 200 ${ }^{\circ} \mathrm{C}$, 空間速度 14,400 で $0.06 \mathrm{gr} / 100 \mathrm{~m}^{3}$ に下げること ができた。

\section{III 実験結果むよびその考察}

\section{1. $\mathrm{Zn}-\mathrm{Cr}-\mathrm{K}_{2} \mathrm{CO}_{3}$ 系に各種金属酸化物の影暃}

実験結果を示すと第 1 表，第 2 表のとおりである。 第 1 表，第 2 表の触媒相成は下のようである。

金属亜鉛, 金属クロム重量比 80:20のものに金属 覀鉛，金属クロムの総重量に対して所定重量比の各種 金属および 20 重量\%の $\mathrm{K}_{2} \mathrm{CO}_{3}$ を加えたものである。 ただし例外として実験番号 124,i208, 292,157,158， $141,142,70,71,80,160,159$ は,それぞれ酸化バナジウ ム, 酸化アルミニウム, 塩化アルミニウム, 珪酸カリ 珪酸カリ, 酸化アルミニウム十珪酸カリ, 酸化マグネ シウム, 硼酸, 硼酸, 軽石, 珪酸カリ, 珪酸カリの重 量\%を示しものである。

また実験番号 157,70,160 は焼成前に実験番号 158， 71,159, は焼成後に添加したものであり，また実験番 号 141 の珪酸力リは焼成後添加したものである。

また実験番号 61-K は炭酸カリの代りに酹酸カリを 加えたものである。

実験番号 143 は $\mathrm{Zn}: \mathrm{Cd}: \mathrm{Cr}: \mathrm{Mo}: \mathrm{K}_{2} \mathrm{CO}_{3}=70$ : 10:20:3:20 の組成で $\mathrm{Zn}$ の一部を $\mathrm{Cd}$ で置換し 
第 1 表 反応温度 $390 \sim 400^{\circ} \mathbf{C}$ 反応王力 200 気圧, 空間速度 $6,000, \mathbf{C O} / \mathbf{H}_{2}=\pi / 2$

\begin{tabular}{|c|c|c|c|c|c|c|c|c|c|c|}
\hline "実験 & & 添 加 & 物 & & $\begin{array}{l}\text { イソブタ, } \\
\text { ール収量 }\end{array}$ & & 生 & 夜 & Vol. \% & \\
\hline 番号 & 触 媒 番 号 & 名 称 & $\overline{w t} \%$ & $\begin{array}{c}\text { gr/cat. } \\
\text { /日 }\end{array}$ & $\left.\mathrm{gr} / \mathrm{m}^{3}\right)^{*}$ & $\begin{array}{l}\text { ×タ } \\
-\quad M\end{array}$ & 水 & 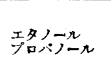 & イ゚ンタター & $\begin{array}{l}\text { 高 沸 } \\
\text { 点留分 }\end{array}$ \\
\hline 34 & $11-B-2$ & $\mathrm{Mn}$ & 20 & 2.5 & $\begin{array}{c}0.405 \\
(0.028)\end{array}$ & 36.5 & $\begin{array}{l}(9.3) \\
41.2\end{array}$ & 13.3 & 1.1 & 5.0 \\
\hline 35 & $21-\mathrm{B}-20$ & $\mathrm{Mn}$ & 10 & 3.6 & $\begin{array}{l}1.14 \\
(0.061)\end{array}$ & $51.5^{\circ}$ & $\begin{array}{l}34.0 \\
(7.9)\end{array}$ & 8.3 & 1.7 & 5.5 \\
\hline 36 & $21-B-2$ & $\mathrm{Mn}$ & 2 & 8.1 & - & - & 96.2 & - & - & - \\
\hline 61 & $51-B-5$ & Mo & 5 & 3.0 & $\begin{array}{l}3.87 \\
(0.219)\end{array}$ & 57.8 & $\begin{array}{l}18.5 \\
(12.23)\end{array}$ & 6.3 & 7.3 & 8.3 \\
\hline 124 & $56-B$ & $\begin{array}{l}\mathrm{Mn} \\
\mathrm{V}_{2} \mathrm{O}_{5} \\
\mathrm{Mo}\end{array}$ & $\begin{array}{r}10 \\
3 \\
3\end{array}$ & 7.0 & $\begin{array}{l}8.7 \\
(0.434)\end{array}$ & 56.8 & $\begin{array}{c}9.2 \\
(16.7)\end{array}$ & 9.9 & 6.2 & 14.1 \\
\hline 208 & $55-B-4$ & $\begin{array}{l}\mathrm{Al}_{2} \mathrm{O}_{3} \\
\mathrm{Mo}\end{array}$ & $\begin{array}{l}4 \\
3\end{array}$ & 2.4 & $\begin{array}{l}2.42 \\
(0.115)\end{array}$ & 53.3 & $\begin{array}{l}(15.1) \\
17.6\end{array}$ & 13.0 & 4.8 & 10.8 \\
\hline 55 & $51-B-3$ & Mo & 3 & 6.9 & $\begin{array}{l}14.8 \\
(0.721)\end{array}$ & 54.7 & $\begin{array}{c}(20.2) \\
10.4\end{array}$ & 6.3 & 10.5 & 17.8 \\
\hline $61-K$ & $\mathrm{~K}-51-\mathrm{B}-3$ & Mo & 3 & 6.6 & $\begin{array}{l}14.9 \\
(0.765)\end{array}$ & 46.0 & $\begin{array}{c}(21.2) \\
14.2\end{array}$ & 6.5 & 11.6 & 18.1 \\
\hline 91 & $61-B-4$ & W & 4 & 5.2 & - & 64.2 & 16.8 & 7.0 & 10. & \\
\hline 205 & $172-\mathrm{B}-2$ & $\mathrm{Mg}$ & 2 & 7.0 & $\begin{array}{l}10.5 \\
(0.511)\end{array}$ & 53.2 & $\begin{array}{l}(17.0) \\
13.5\end{array}$ & 6.8 & 7.3 & 15.3 \\
\hline 204 & $171-B-2$ & $\mathrm{Ca}$ & 2 & 6.9 & $\begin{array}{l}13.6 \\
(0.621)\end{array}$ & 45.8 & $\begin{array}{c}(18.4) \\
19.0\end{array}$ & 7.8 & 9.0 & 15.3 \\
\hline 206 & $173-B-2$ & $\mathrm{Ba}$ & 2 & 4.5 & $\begin{array}{l}11.8 \\
(0.52)\end{array}$ & 23.5 & $\begin{array}{c}(19.0) \\
37.3\end{array}$ & 11.2 & 11.5 & 11.2 \\
\hline 213 & $177-B-2$ & Co & 2 & 6.9 & $\begin{array}{l}8.5 \\
(0.414)\end{array}$ & 58.0 & $\begin{array}{c}(15.0) \\
13.8\end{array}$ & 6.0 & 6.0 & 13.9 \\
\hline 207 & $174-B-2$ & Th & 2 & 6.8 & $\begin{array}{l}15.8 \\
(0.815) \\
8.85\end{array}$ & 46.5 & $\begin{array}{l}(20.5) \\
14.4\end{array}$ & 8.9 & 12.0 & 15.2 \\
\hline 269 & $175-B-1$ & $\mathrm{Fe}$ & 1 & 5.9 & $\begin{array}{l}8.85 \\
(0.413)\end{array}$ & 54.0 & $\begin{array}{c}(17.2) \\
13.7\end{array}$ & 9.5 & 7.0 & 14.2 \\
\hline 292 & $176-\mathrm{B}-1$ & $\mathrm{AlCl}_{3}$ & 0.1 & 6.4 & $\begin{array}{l}15.2 \\
(0.68)\end{array}$ & 46.0 & $\begin{array}{l}(22.8) \\
10.2\end{array}$ & 10.3 & 10.6 & 19.0 \\
\hline 157 & $83-B-2-3$ & $\mathrm{~K}_{2} \mathrm{SiO}_{3}$ & 2 & 7.0 & $\begin{array}{l}4.17 \\
(0.196) \\
12.0\end{array}$ & 13.8 & $\begin{array}{c}(12.9) \\
54.5 \\
(17.5)\end{array}$ & 17.7 & 2.8 & 6.4 \\
\hline 158 & $83-B-2-3$ & $\mathrm{~K}_{2} \mathrm{SiO}_{3}$ & 2 & 7.4 & $(0.62)$ & 53.4 & 12.9 & 10.6 & 8.4 & 12.7 \\
\hline 141 & $82-B-2$ & $\begin{array}{l}\mathrm{Al}_{2} \mathrm{O}_{3} \\
\mathrm{~K}_{2} \mathrm{SiO}_{3}\end{array}$ & $\begin{array}{l}2 \\
2\end{array}$ & 8.1 & $\begin{array}{l}12.5 \\
(0.67) \\
3.95\end{array}$ & 58.5 & $\begin{array}{l}(17.5) \\
10.8\end{array}$ & 8.1 & 8.3 & 14.3 \\
\hline 142 & $81-B-2$ & $\mathrm{MgO}$ & 2 & 4.6 & $\begin{array}{l}3.95 \\
(0.221)\end{array}$ & 63.5 & 10.6 & 16.3 & 4.8 & 8.7 \\
\hline 143 & $90-B-10$ & $\mathrm{Cd}$ & 10 & 5.7 & $\begin{array}{l}17.6 \\
(0.825)\end{array}$ & 28.5 & $\begin{array}{l}(23.2) \\
27.4\end{array}$ & 7.1 & 14.5 & 18.1 \\
\hline
\end{tabular}

たものである。

第1表よりふかるように生成液量は $\mathrm{Mo}, \mathrm{Cd}, \mathrm{Ca}$, $\mathrm{Co}, \mathrm{Th}, \mathrm{AlCl}_{3}$, 珪酸力り添加のものが多く, イソブタ ノール收率は $\mathrm{Mo}, \mathrm{Ba}, \mathrm{Th}, \mathrm{AlCl}_{3}, \mathrm{Cd}$ 添加のものが大 である。Mo 添加のものについては他の金属との併存
よりの単独の場合が良好で, またその場合炭酸カリ， 酰酸カリの場合を比較すると前者の方が生成水が少く メタノール収率が多い。その他のアルコール収率なら びに生成量については大差がない。珪酸カリは触媒の 焼成前加えるよりも燒成後の方がよい結果を得てい 


\section{第 2 表 反応温度 $420^{\circ} \mathrm{C}$, 反応圧力 200 気圧, 空間速度 $6,000 \mathrm{CO} / \mathrm{H}_{2}=\mathrm{I} / 2$}

\begin{tabular}{|c|c|c|c|c|c|c|c|c|c|c|}
\hline 害験 & & & & 生成液量 & イソブタノ & & 成 & 液 & Vol. \% & \\
\hline 天塥 & 触媒番号 & 添 加 & & gr/cat.cc & $\begin{array}{c}\text { 一 ル収量 } \\
\mathrm{gr/m}{ }^{3} \\
(\mathrm{CO}) *\end{array}$ & 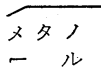 & 水 & 玨少デー & イ゚ンナター & $\begin{array}{l}\text { 高沸点 } \\
\text { 留 }\end{array}$ \\
\hline 62 & $21-B-20$ & $\begin{array}{l}\text { 名 } \\
\mathrm{Mn}\end{array}$ & wt $\%$ & 5.5 & $\begin{array}{c}2.06 \\
(0.115)\end{array}$ & 44.7 & $\begin{array}{l}(7.7) \\
37.1\end{array}$ & 5.9 & 2.1 & 5.3 \\
\hline 64 & $31-B-20$ & $\mathrm{Mg}$ & 10 & 3.7 & $\begin{array}{c}2.95 \\
(0.158)\end{array}$ & 37.7 & $\begin{array}{c}(11.2) \\
27.6\end{array}$ & 13.9 & 4.0 & 13.6 \\
\hline 39 & $71-\mathrm{B}-5$ & V & 5 & 8.0 & $\begin{array}{c}23.4 \\
(1.34)\end{array}$ & 25.6 & $\begin{array}{c}(29.3) \\
21.6\end{array}$ & 12.0 & 16.8 & 20.7 \\
\hline 65 & $71-B-20$ & $\mathrm{~V}$ & 20 & 6.2 & $\begin{array}{l}16.4 \\
(0.9)\end{array}$ & 32.8 & $\begin{array}{l}(21.2) \\
28.4\end{array}$ & 10.8. & 14.5 & 12.4 \\
\hline 66 & $51-B-5$ & Mo & 5 & 7.2 & $\begin{array}{c}13.8 \\
(0.720)\end{array}$ & 44.7 & $\begin{array}{l}(20.2) \\
18.2\end{array}$ & 11.5 & 10.0 & 14.8 \\
\hline 56 & $51-B-3$ & Mo & 3 & 6.7 & $\begin{array}{c}26.7 \\
(1.42)\end{array}$ & 27.9 & $\begin{array}{l}(30.9) \\
19.3\end{array}$ & 9.3 & 21.2 & 21.1 \\
\hline 68 & $61-B-5$ & W & 5 & 4.9 & $\begin{array}{c}14.8 \\
(0.77)\end{array}$ & 28.8 & $\begin{array}{c}(25.2) \\
22.7\end{array}$ & 13.4 & 15.7 & 16.6 \\
\hline 92 & $61-B-4$ & W & 4 & 6.1 & $\begin{array}{c}21.4 \\
(1.08)\end{array}$ & 30.9 & $\begin{array}{l}(25.0) \\
25.5\end{array}$ & 5.5 & 17.8 & 17.0 \\
\hline 70 & $41-B-5$ & $\mathrm{H}_{3} \mathrm{BO}_{4}$ & 5 & 4.6 & $\begin{array}{c}2.47 \\
(0.129)\end{array}$ & 25.4 & $\begin{array}{l}(7.8) \\
57.4\end{array}$ & 8.3 & 2.8 & 4.3 \\
\hline 71 & $42-B-5$ & $\mathrm{H}_{3} \mathrm{BO}_{4}$ & 5 & 2.6 & $\begin{array}{c}3.1 \\
(0.156)\end{array}$ & 38.4 & $\begin{array}{c}(13.9) \\
31.8\end{array}$ & 7.5 & 6.0 & 8.7 \\
\hline 80 & $6-B-20$ & 軽 石 & 50 & 5.1 & $\begin{array}{r}5.1 \\
(0.24)\end{array}$ & 11.7 & $\begin{array}{l}(6.2) \\
76.8\end{array}$ & 4.5 & 4.7 & 2.5 \\
\hline 160 & $83-B-2$ & $\mathrm{~K}_{2} \mathrm{SiO}_{3}$ & 2 & 7.3 & $\begin{array}{c}12.0 \\
(0.605)\end{array}$ & 22.0 & 42.5 & 14.1 & 8.3 & 7.7 \\
\hline 159 & $83-B-2$ & $\mathrm{~K}_{2} \mathrm{SiO}_{3}$ & 2 & 6.4 & $\begin{array}{c}13.6 \\
(0.675)\end{array}$ & 27.8 & 18.2 & 25.6 & 10.5 & 17.3 \\
\hline
\end{tabular}

る。結局イソブタノール収量 (gr./原料ガス中の $\mathrm{CO}$, $\left.\mathrm{m}^{3}\right)$ は $\mathrm{Cd}, \mathrm{Th}, \mathrm{AlCl}_{3}, \mathrm{Mo}$ を加えたものが良好でそれ ぞれ 17.6,15.8,15.2,14.9 を得た。

第 2 表の $420^{\circ} \mathrm{C}$ の場合は生成液量はバナジウム, モリブデン，タングステン，珪酸カリ添加の場合が良 好でイソブタノール収率はモリブデン, バナジウム， タングステンの時が良好で特にモリブデン $3 \%$ の時が 優秀である。またモリブデン $3 \%$ の時はアルコール生 成に伴う理論生成水量よりも生成水量は非常に少い。 すなわちイソブタノール収量 (gr./原料ガス中の CO, $\mathrm{m}^{3}$ ) は Mo の時が最も多くて 26.7, V は 23.4 でこ れに次いで良好であつた。

次第 3 表, 第 4 表にガス分析結果㧍よびガス消費 率を示す。

これらのガス分析結果をみるとメタンの生成は余り 大ではないが水の生成が多いと $\mathrm{CO}_{2}$ と共にかなり増 加を示している。また $\mathrm{CO}_{2}, \mathrm{CH}_{4}$ の量は反応温度が 高い程増加している。 $\mathrm{CO}: \mathrm{H}_{2}$ 消費率は反応温度 400 ${ }^{\circ} \mathrm{C}$ の場合は 0.5 2 の範囲であり，そのうち良好と考
えられる Mo 添加の場合は 1:1 の值を示している。 反応温度を $420^{\circ} \mathrm{C}$ 亿上昇すると $\mathrm{CO}$ の消費は増加し $\mathrm{CO}: \mathrm{H}_{2}$ 消費率は $3: 1$ ～ $1: 1$ の範囲となつている。 Mo 添加の場合は $1.4: 1$ である。最良の成績を示した Mo3\% の場合について原料ガス, 反応ガスの通過量 ならびにガス分析結果と, $n \mathrm{CO}+2 n \mathrm{H}_{2}=\mathrm{C}_{n} \mathrm{H}_{2 n+1} \mathrm{OH}$ $+(n+1)_{2} \mathrm{HO}(1)$ にもとゔいての生成水量を生成了 ルコール量から計算すると, $\mathrm{CO}+\mathrm{H}_{2} \mathrm{O}=\mathrm{CO}_{2}+\mathrm{H}_{2}(2)$ の水性ガスが起つていることがわかる。このことから Mo 海䚢上から生成水を（2）の反応によつて除去 し，触媒の活性を大にしている㗢きを示しているもの と考えられる。

すなわち Mo は (1) の反応の外に $(2 n-1) \mathrm{CO}+(n$ $+1) \mathrm{H}_{2}=\mathrm{C}_{n} \mathrm{H}_{2 n+1} \mathrm{OH}+(n-1) \mathrm{CO}_{2}$ (3) の反応を促進 する働きをしていることがわかる。 $\mathrm{Mo}$ は $\mathrm{Zn}-\mathrm{K}_{2} \mathrm{CO}_{3}$. 系においては水の生成を促進する作用を示したが， $\mathrm{Zn}-\mathrm{Cr}-\mathrm{K}_{2} \mathrm{CO}_{3}$ 系の場合に扔いてはイソブタノール合 成を侵進し，(2) の水性ガス反応によつて生成液にお ける水の生成を抑制する作用を持つていることがわか. 
第3表 反応温度 $400^{\circ} \mathrm{C}$ の場合

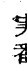

実匼

番号 $\mathrm{CO}_{2} \mathrm{O}_{2} \mathrm{CO} \quad \mathrm{H}_{2}$

$\begin{array}{lllll}34 & 0.4 & 0.0 & 34.8 & 59.3\end{array}$

$\begin{array}{lllll}36 & 0.3 & 0.0 & 32.7 & 62.0\end{array}$

$\begin{array}{lllll}124 & 0.3 & 0.0 & 30.8 & 65.7\end{array}$

$\begin{array}{lllll}208 & 2.2 & 0.0 & 31.5 & 60.6\end{array}$

$\begin{array}{lllll}55 & 0.2 & 0.0 & 30.2 & 59.5\end{array}$

$\begin{array}{lllll}91 & 1.2 & 0.0 & 31.6 & 55.7\end{array}$

$\begin{array}{lllll}205 & 2.1 & 0.0 & 29.8 & 59.1\end{array}$

$\begin{array}{lllll}204 & 2.3 & 0.0 & 28.3 & 57.0\end{array}$

$\begin{array}{lllll}213 & 1.3 & 0.0 & 30.4 & 60.0\end{array}$

$\begin{array}{lllll}207 & 1.6 & 0.0 & 31.9 & 59.4\end{array}$

$\begin{array}{lllll}269 & 1.1 & 0.1 & 29.5 & 62.4\end{array}$

$\begin{array}{lllll}292 & 1.8 & 0.3 & 28.1 & 63.0\end{array}$

$\begin{array}{lllll}157 & 2.2 & 0.0 & 31.1 & 61.8\end{array}$

$\begin{array}{lllll}158 & 2.2 & 0.0 & 31.1 & 61.8\end{array}$

$\begin{array}{lllll}141 & 0.5 & 0.0 & 32.6 & 57.0\end{array}$

第3衰文心温度 $400 \circ \mathrm{C}$ 場合

\begin{tabular}{|c|c|c|c|c|c|c|c|c|}
\hline & 反 & 応 & 瓦 & 斯 & & & 瓦斯 & $\mathrm{CO}$ \\
\hline $\mathrm{CO}_{2}$ & $\mathrm{O}_{2}$ & $\mathrm{C}_{n} \mathrm{H}_{m}$ & $\mathrm{CO}$ & $\mathrm{H}_{2}$ & $\mathrm{CH}_{4}$ & $\mathrm{~N}_{2}$ & $\mathrm{CO} / \mathrm{H}_{2}$ & Vol. \%. \\
\hline 4.7 & 0.0 & 0.2 & 26.5 & 57.2 & 4.1 & 7.3 & 2 & 33.2 \\
\hline 2.2 & 0.0 & 0.0 & 24.5 & 62.0 & 2.3 & 9.0 & 1.66 & - \\
\hline 1.0 & 0.0 & 0.2 & 29.7 & 65.2 & 1.4 & 2.5 & 0.5 & 14.2 \\
\hline 4.0 & 0.0 & 0.3 & 28.3 & 56.6 & 4.0 & 6.8 & 0.7 & 13.9 \\
\hline 1.5 & 0.0 & 0.1 & 27.3 & 57.8 & 5.5 & 7.7 & 1.0 & 20.0 \\
\hline 1.8 & 0.0 & 0.2 & 29.8 & 56.6 & 4.5 & 7.1 & 1.0 & 12.9 \\
\hline 3.5 & 0.0 & 0.2 & 24.0 & 54.4 & 7.0 & 10.9 & 0.8 & 28.8 \\
\hline 4.8 & 0.0 & 0.4 & 23.3 & 54.9 & 4.7 & 12.1 & 1.0 & 26.8 \\
\hline 3.4 & 0.0 & 0.4 & 27.4 & 59.5 & 2.2 & 7.5 & 0.5 & 19.7 \\
\hline 2.4 & 0.0 & 0.2 & 24.2 & 59.4 & 0.2 & 8.4 & 1.8 & 32.5 \\
\hline 3.6 & 0.0 & 0.2 & 24.2 & 58.8 & 4.6 & 7.6 & 0.8 & 25.0 \\
\hline 3.6 & 0.0 & 0.2 & 25.4 & 56.0 & 4.7 & 10.1 & 0.4 & 18.7 \\
\hline 5.1 & 0.0 & 0.7 & 25.0 & 59.8 & 4.0 & 5.4 & 1.1 & 23.1 \\
\hline 3.6 & 0.0 & 0.5 & 28.6 & 57.8 & 2.4 & 5.1 & 0.9 & 18.8 \\
\hline 1.9 & 0.0 & 0.4 & 28.9 & 55.4 & 3.9 & 9.5 & 1.0 & 22.7 \\
\hline
\end{tabular}

\section{第4表反応温度 $420^{\circ} \mathrm{C}$ の場合}

\begin{tabular}{|c|c|c|c|c|c|c|c|c|c|c|c|c|c|c|c|}
\hline \multirow{2}{*}{ 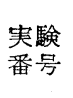 } & & 原 & 料。 & 瓦 & 斯 & & & 応 & 瓦 & 析 & \multirow{2}{*}{\multicolumn{2}{|c|}{ 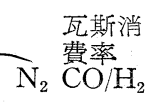 }} & \multirow{2}{*}{$\begin{array}{l}\mathrm{CO} \\
\text { 変化率 } \\
\text { Vol \% }\end{array}$} \\
\hline & $\widetilde{\mathrm{CO}_{2}}$ & $\mathrm{O}_{2}$ & $\mathrm{CO}$ & $\mathrm{H}_{2}$ & $\mathrm{CH}_{4}$ & $\mathrm{~N}_{2}$ & $\mathrm{CO}_{2}$ & $\mathrm{O}_{2}$ & $\mathrm{C}_{n} \mathrm{H}_{m}$ & $\widehat{\mathrm{CO}}$ & $\mathrm{H}_{2}$ & $\mathrm{CH}_{4}$ & & & \\
\hline 64 & 0.4 & 0.4 & 34.8 & 59.3 & 0.0 & 5.1 & 3.8 & 0.0 & 0.0 & 27.7 & 59.2 & 2.8 & 6.7 & 2.7 & 24.7 \\
\hline 66 & 0.6 & 0.0 & 32.0 & 60.4 & 1.3 & 5.7 & 6.4 & 0.0 & 0.2 & 25.2 & 56.0 & 1.3 & 10.9 & 1.0 & 30. \\
\hline 56 & 1.1 & 0.0 & 32.7 & 58.5 & 3.9 & 3.8 & 3.0 & 0.0 & 0.6 & 25.3 & 57.4 & 5.4 & 8.6 & 1.4 & 31.0 \\
\hline 68 & 0.8 & 0.2 & 33.3 & 61.2 & 1.8 & 1.7 & 4.3 & 0.0 & 0.5 & 26.5 & 57.7 & 4.7 & $6.3^{\circ}$ & 2.0 & 7.0 \\
\hline 92 & 1.2 & 0.0 & 31.6 & 55.7 & 4.5 & 7.0 & 4.4 & 0.0 & 0.4 & 25.5 & 54.5 & 7.0 & 8.2 & 1.4 & 7. \\
\hline 70 & 0.0 & 0.3 & 33.4 & 62.3 & 0.7 & 3.3 & 3.2 & 0.0 & 0.0 & 28.8 & 56.5 & 3.4 & 8.1 & 0.6 & 20. \\
\hline 71 & 0.0 & 0.3 & 33.4 & 62.3 & 0.7 & 3.3 & 4.3 & 0.0 & 0.4 & 27.9 & 59.7 & 1.9 & 5.8 & 1.1 & 20. \\
\hline 80 & 2.0 & 0.0 & 29.3 & 59.6 & 2.0 & 7.1 & 10.5 & 0.0 & 1.7 & 15.8 & 54.1 & 10.8 & 7.1 & 1.4 & 50. \\
\hline 50 & 2.2 & 0.0 & 31.1 & 61.8 & 1.7 & 3.2 & 3.6 & 0.0 & 0.5 & 27.6 & 59.8 & 2.4 & 5.1 & 0.8 & \\
\hline
\end{tabular}

る。このことがこの添加剤の優秀性を示していると考 えられる。

\section{2. 生成熱の概算}

一酸化炭素と水素よりアルコール類が合成される反 応は次の二式であらわされる。

$$
\begin{aligned}
& n \mathrm{CO}+2 n \mathrm{H}_{2}=\mathrm{C}_{n} \mathrm{H}_{2 n+1} \mathrm{OH}+(n-1) \mathrm{H}_{2} \mathrm{O} \\
& (2 n-1) \mathrm{CO}+(n+1) \mathrm{H}_{2}=\mathrm{C}_{n} \mathrm{H}_{n+1} \mathrm{OH} \\
& \quad+(n-1) \mathrm{CO}_{2}
\end{aligned}
$$

またこの主反応に伴つて次の副反応が起るものと考 えられる。

$$
\begin{aligned}
& \mathrm{CO}+3 \mathrm{H}_{2}=\mathrm{CH}_{4}+\mathrm{H}_{2} \mathrm{O}+49.0 \mathrm{kcal} / \mathrm{mol} \\
& 2 \mathrm{CO}+2 \mathrm{H}_{2}=\mathrm{CH}_{4}+\mathrm{CO}_{2}+59.07 \mathrm{kcal} / \mathrm{mol} \\
& 2 \mathrm{CO}=\mathrm{CO}_{2}+\mathrm{C}-40.9 \mathrm{kcal} / \mathrm{mol} \\
& \mathrm{CO}+\mathrm{H}_{2} \mathrm{O}=\mathrm{CO}_{2}+\mathrm{H}_{2}+10.4 \mathrm{kcal} / \mathrm{mol}
\end{aligned}
$$

つぎに $(\mathrm{A})$ (B) 両式に従つて各種アルコール類 $1 \mathrm{~kg}$
当りの生成熱はつぎのようである。

$\begin{array}{lcc} & \text { A式より } & \text { B式より } \\ \text { メタノール } & 759 \mathrm{kcal} / \mathrm{kg} & 759 \mathrm{kcal} / \mathrm{kg} \\ \text { エタノール } & 1,314 & 1,544 \\ \text { プロパノール } & 1,620 & 1,968 \\ \text { イソブタノール } & 1,810 & 2,228 \\ \text { nーオクタノール } & 2,135 & 2,700\end{array}$

今実験番号 55 の合成結果ならびにガス分析結果を 参照して概算する。

つぎのような仮定をおく。

エタノールプロパノール留分中にはェタノール, プ ロパノールは等量含有されている, 高沸点部分はオク タノールと仮定した。

実験番号 55 のアルコールより生所される理論水量 は(A)式によるとつぎのようである。 


\begin{tabular}{|c|c|}
\hline × $>-ル$ & $\mathrm{O}$ \\
\hline エタ, & $3.1 \mathrm{gr} \times 18 / 46=1.22 \mathrm{gr}$ \\
\hline プロパノール & $3.1 \mathrm{gr} \times 36 / 60=1.86 \mathrm{gr}$ \\
\hline イソブタノール & $10.2 \mathrm{gr} \times 54 / 74=7.45 \mathrm{gr}$ \\
\hline オクタノール & $17.8 \mathrm{hr} \times 126 / 130=17.3 \mathrm{gr}$ \\
\hline 計 & $27.83 \mathrm{gr}$ \\
\hline
\end{tabular}

すなわち $100 \mathrm{gr}$ の生成液当り $27.83 \mathrm{gr}$ の生成水が できることになる。しかる $12.8 \mathrm{gr}$ しか実際は生成し ていないので $27.83 \mathrm{gr}-12.8 \mathrm{gr}=15.03 \mathrm{gr}$ は $\mathrm{H}_{2} \mathrm{O}+\mathrm{CO}$ $=\mathrm{H}_{2}+\mathrm{CO}_{2}$ の水性ガス反応によつて消失したものと 考えられる。

またこの時大口ガス量は $2310.3 l$, 出口ガス量 $2087 l$ である。そこで出入口ガス量とガス分析結果より $\mathrm{CO}_{2}$, $\mathrm{CH}_{4}$ の増加量を計算すると $\mathrm{CO}_{2}$ は $26.7 l, \mathrm{CH}_{4}$ は $10.9 l$ の増量となる。

前述の $15.03 \mathrm{gr}$ の水より水性ガス反応により生成し た炭酸ガスの量は $18.7 l$ となるから $26.7-18.7 l=8.0 l$ の $\mathrm{CO}_{2}$ は $2 \mathrm{CO}+2 \mathrm{H}_{2}=\mathrm{CH}_{4}+\mathrm{CO}_{2}$ の反応によつて生 成したと考えてみる。これは $\mathrm{CH}_{4}$ の増加量 $10.9 l$ と ほぼ一致する。

そこでつぎのよらな反応が起つたものと考える。

$$
n \mathrm{CO}+2 n \mathrm{H}_{2}=\mathrm{C}_{n} \mathrm{H}_{2 n+1} \mathrm{OH}+(n-1) \mathrm{H}_{2} \mathrm{O}
$$

(A)反忘による生成水の一部はつぎの水性ガス反応に よつて消費される。

$$
\mathrm{CO}+\mathrm{H}_{2} \mathrm{O}=\mathrm{CO}_{2}+\mathrm{H}_{2}
$$

すなわち

$$
\begin{aligned}
& (2 n-1) \mathrm{CO}+(n+1) \mathrm{H}_{2}=\mathrm{C}_{n} \mathrm{H}_{2 n+1} \mathrm{OH} \\
& \quad+(n-1) \mathrm{CO}_{2}
\end{aligned}
$$

の反応が一部起つている。

またこの反応による以外に $\mathrm{CO}_{2}$ はつぎの反応によ つて生成する。

$$
2 \mathrm{CO}+2 \mathrm{H}_{2}=\mathrm{CH}_{4}+\mathrm{CO}_{2}
$$

その他復雑な反応が起つているであろらが三反応にも とづくものとして生成液 $1 \mathrm{~kg}$ について (A) 式にも とつきき $1,056 \mathrm{kcal},(\mathrm{F})$ 式，(D)式にもとついて 86.7 $\mathrm{kcal}, 211 \mathrm{kcal}$ の生成熱を得る。そこで生成液 $1 \mathrm{~kg}$ を 生成するに注これらの総和 $1353.7 \mathrm{kcal} / \mathrm{kg}$ が発生する ことになる。同様にして実験番号 56 の合成結果なら びにガス分析結果より概算すると大体上記と同様の反 応が起つていることが推定され, 反応温度 $420^{\circ} \mathrm{C}$ の 場合の生成熱 $1 \mathrm{~kg}$ 当りの生成熱 $1,674 \mathrm{kcal}$ を得る。 これらの生成熱は反応温度 $400^{\circ} \mathrm{C}, 420^{\circ} \mathrm{C}$ において夫 々メタノール合成反応の場合の 1.4 倍, 1.7 倍に当る。
実際は色々な副反応を伴らものであるからこれよりも 大きくなるものと考えられ, 工業的合成塔の設計に際 しては特別の考慮が必要と考えられる。

\section{IV 総 括}

1. $\mathrm{Zn}: \mathrm{Cr}: \mathrm{K}_{2} \mathrm{CO}_{3}=80: 20: 20$ 組成の触媒に対 乙 Mn, Mo, W, V, Mg, Ca, Ba, Co, Th, Fe, Mn $+\mathrm{V}_{2} \mathrm{O}_{5}$. $+\mathrm{Mo}, \mathrm{Al}_{2} \mathrm{O}_{3}+\mathrm{Mo}, \mathrm{K}_{2} \mathrm{SiO}_{3}, \mathrm{H}_{3} \mathrm{BO}_{4}, \mathrm{AlCl}_{3}$ などを添加. し影響を調へた。実験条件は反応温度 $400 \sim 420^{\circ} \mathrm{C}$, 反応圧力 200 気圧, $\mathrm{CO}: \mathrm{H}_{2}=1: 2$, 空間速度 6,000 を使用した。

2. これらの添加物中 Mo が最も良好促進剤である ことを発見した。Mo の作用として考えられることは， $\mathrm{Zn}-\mathrm{K}_{2} \mathrm{CO}_{3}$ 系に $\mathrm{Mo}$ 少添加するとほとんど水の生成反 応のみであるのに $\mathrm{Zn}-\mathrm{Cr}-\mathrm{K}_{2} \mathrm{CO}_{3}$ 系に添加すると $\mathrm{Zn}$ $\mathrm{Cr}-\mathrm{K}_{2} \mathrm{CO}_{3}$ 系の場合よりも水の生成は減少しイソブタ ノール収率は向上する。これはアルコールの縮合反応 によつて生成する水を水性ガス反応によつて除去し触 媒性能を向上させているものと考えられる。もちろん カリとの共存においてその作用が促進される。

3. Mo,Th,W :はイソブタノール触媒の良い添加剤 であり $\mathrm{CO}_{2}, \mathrm{CH}_{4}$ の生成反応は他の添加剤に比較し ても少い。この点でも工業上良好な添加剤である。

4. 反応温度 $400^{\circ} \mathrm{C}$ の場合は $\mathrm{CO}: \mathrm{H}_{2}$, 消費率が $1: 1$ また $420^{\circ} \mathrm{C}$ の場合は $1.4: 1$ の時イソブタノ一 ル収率は良好である。

5. 実験番号 55,56 について生成熱の計算を行い区 応温度 $400^{\circ} \mathrm{C}, 420^{\circ} \mathrm{C}$ の場合夫々生成液 $1 \mathrm{~kg}$ 当り $1353.7 \mathrm{kcal}, 1,674 \mathrm{kcal}$ となり,メ夕ノール合成の場合 の 1.4 倍, 1.7 倍に当り工業上反応塔の設計について は特別の工夫が必要である。

6. 生成熱の計算においてつぎのような反応が主と して起つていることがわかつた。

$$
\begin{aligned}
& n \mathrm{CO}+2 n \mathrm{H}_{2}=\mathrm{C}_{n} \mathrm{H}_{2} n+1 \mathrm{OH}+(n-1) \mathrm{H}_{2} \mathrm{O} \\
& \mathrm{CO}+\mathrm{H}_{2} \mathrm{O}=\mathrm{CO}_{2}+\mathrm{H}_{2}
\end{aligned}
$$

(A)(B)の組合せによる

$$
\begin{aligned}
& (2 n-1) \mathrm{CO}+(n+1) \mathrm{H}_{2}=\mathrm{C}_{n} \mathrm{H}_{2 n \div 1} \mathrm{OH} \\
& \quad+(n-1) \mathrm{CO}_{2}
\end{aligned}
$$

その他

$$
2 \mathrm{CO}+2 \mathrm{H}_{2}=\mathrm{CH}_{4}+\mathrm{CO}_{2}
$$

最後に終始御指導いただきました藤村建支氏，なら びにこの研究に協力下さつた斎藤利家氏また本稿の発 表を御許可下さつた新居浜製造所長大隅改介氏ならび に研究部長平田稔氏に厚く感謝の意を表す。 


\title{
Studies for synthesis of Isobutanol from Carbon Monoxide and Hydrogen (II)
}

\author{
by Toshihede Gotoh \\ (Sumitomo Kagaku Kogyo Co.)
}

\begin{abstract}
SYNOPSIS :-Because, in the first report, we understood that chrome is a most suitable promoter for $\mathrm{Zn}$-alkali system, we investigated in this report the effects of various metal oxides for $\mathrm{Zn}$-Cr-alkali system.

As results of this investigation, we found that Mo, Th and $\mathrm{W}$ are good, especially Mo is most excellent.

In case of $\mathrm{Zn}$-Alkali system, addition of Mo promoted only formation of water, but we discovered that they have more excellent character by co-existense of $\mathrm{Cr}$.

Specially, as distinctive feature of Mo, we think that formation of water is less than theoretical quantity viz. promotes following reaction

$$
(2 n-1) \mathrm{CO}+(n+1) \mathrm{H}_{2}=\mathrm{C}_{n} \mathrm{H}_{2 n+1} \mathrm{OH}+(n-1) \mathrm{CO}_{2} \text {. }
$$

Also we estimated roughly heat of formation about this system catalyser and we found that at temperature $400^{\circ} \mathrm{C}$ and $420^{\circ} \mathrm{C}, 1,354 \mathrm{kcal}$ and $1,674 \mathrm{kcal}$ are respectively generated per liquid of formation $1 \mathrm{~kg}$.
\end{abstract}

\section{会費払込みについて}

本年度本会々費未納の方は，下記により早急に御払込み下さいますようお願い致します。

$\begin{array}{cll}\text { 昭和35年度 } & \text { 特別会員会費 (1口) } & 7.000 \text { 円 } \\ \text { " } & \text { 正会員会費 " } & 1.000 \text { 円 }\end{array}$

振替口來東 京 55504 番

Tel. 東 京 (561) 3760 番 